\title{
Benign Ovarian Transitional Cell Tumor
}

National Cancer Institute

\section{Source}

National Cancer Institute. Benign Ovarian Transitional Cell Tumor. NCI Thesaurus. Code C40087.

A non-metastasizing neoplasm that arises from the ovary and is characterized by the presence of neoplastic epithelial cells that resemble urothelial cells. 